Provided for non-commercial research and education use. Not for reproduction, distribution or commercial use.

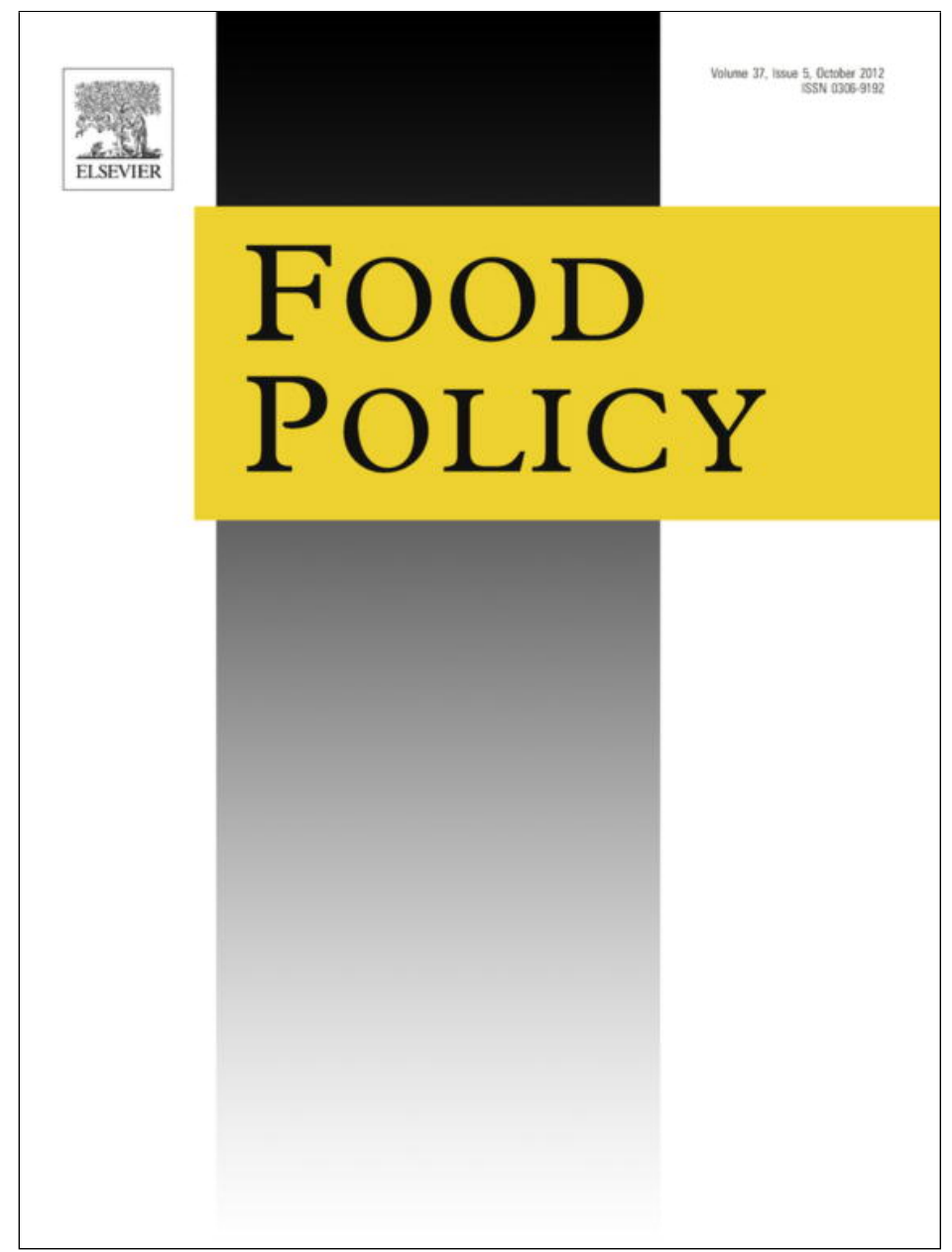

This article appeared in a journal published by Elsevier. The attached copy is furnished to the author for internal non-commercial research and education use, including for instruction at the authors institution and sharing with colleagues.

Other uses, including reproduction and distribution, or selling or licensing copies, or posting to personal, institutional or third party websites are prohibited.

In most cases authors are permitted to post their version of the article (e.g. in Word or Tex form) to their personal website or institutional repository. Authors requiring further information regarding Elsevier's archiving and manuscript policies are encouraged to visit:

http://www.elsevier.com/copyright 


\title{
Export behavior of Italian food firms: Does product quality matter?
}

\author{
Daniele Curzi ${ }^{\mathrm{a}}$, Alessandro Olper ${ }^{\mathrm{a}, \mathrm{b}, *}$ \\ ${ }^{a}$ Department of Economics, Management and Quantitative Methods (DEMM), Università degli Studi di Milano, Italy \\ ${ }^{\mathrm{b}}$ LICOS - Centre for Institution and Economic Performance, Catholic University of Leuven, Belgium
}

\section{A R T I C L E I N F O}

\section{Article history:}

Received 9 May 2011

Received in revised form 3 May 2012

Accepted 18 May 2012

Available online 23 June 2012

\section{Keywords:}

Firms heterogeneity

Total factor productivity

Quality

Export behavior

Food industry

\begin{abstract}
A B S T R A C T
Using firm-level data we investigate the export behavior of Italian food firms, focusing on the link between total factor productivity (TFP), product quality, and export across heterogeneous destinations. We test the main predictions of an international trade model based on firm heterogeneity in product quality and non-homothetic preferences in consumption. In this setting, the firm's export intensity should be increasing in the per-capita income of foreign destinations, and the effect should be largely driven by firms' heterogeneity in product quality. Using different measures of revenue-TFP, and different proxies for product quality, we find strong support for the main model predictions. Moreover, consistent with the Alchian-Allen effect, we find a positive relationship between the quality of exported products and the distance of destination countries.
\end{abstract}

(c) 2012 Elsevier Ltd. All rights reserved.

\section{Introduction}

Empirical evidence and theoretical models increasingly point to the importance of product quality for understanding the patterns of international trade. The quality of traded products is of primary importance, especially because economic growth and development are driven by the total factor productivity (TFP) that rises as a result of innovation, either reducing costs, or, indeed, increasing the quality of the input and the final products (Helpman, 2011). ${ }^{1}$

The quantification of the role of quality in explaining trade outcomes is, however, prevent by the lack of direct measures of quality, forcing researchers to use proxies such as unit values computed from trade statistics (Crozet et al., 2012; Hallak and Schott,

\footnotetext{
* Corresponding author at: Università degli Studi di Milano, via Celoria 2, I-20133 Milano, Italy. Tel.: +3902 50316481; fax: +390250316486.

E-mail address: alessandro.olper@unimi.it (A. Olper).

1 See Linder (1961), Falvey and Kierzkowski (1987), and Flam and Helpman (1987) for seminal contributions studying the influence of product quality on international trade. Empirical evidence of the link between product quality and trade patterns can be find in Schott (2004) and Hallak (2010). Differently, firms' level evidence can be found in Verhoogen (2008). The contribution of product quality to macroeconomic growth is investigated theoretically by Grossman and Helpman (1991) and empirically by Hummels and Klenow (2005).
}

2011). However, it is well known that the use of unit values introduces noise in the analysis because unit values also capture several aspects that are not attributable to quality. ${ }^{2}$

In this paper we use an alternative approach to study the relationship between product quality and food export performance. Specifically, we make use of a (unbalanced) panel of roughly 750 Italian food firms, observed in the period 2001-2006. The main advantage of our dataset is that it allows the construction of a large set of firm-level variables, strictly correlated with product quality, like investment intensity, R\&D expenditure, product and process innovations, as well as quality standard certifications. Using this data we study the relationship between TFP, product quality and firms export across destinations.

The empirical analysis is based on a theoretical model recently developed by Crinò and Epifani (forthcoming), who extend a heterogeneous-firm's model a la Melitz (2003) by incorporating firms heterogeneity in product quality and non-homothetic preferences. In this setting, they show that, conditional to export, firm's export intensity monotonically increases in the per-capita income of export destinations and, most importantly, this effect should be largely driven by firms heterogeneity in product quality.

\footnotetext{
2 First, because product heterogeneity and classification errors are important sources of unit value noise (Lipsey, 1994). Second, because higher unit values could reflect higher quality but also higher costs (see Aiginger, 1997). Finally because higher unit values could also be the consequence of higher margins created by market power (Knetter, 1997). See Hallak and Schott (2011) and Khandelwal (2010), for recent evidence about the poor ability of export unit values to capture product quality.
} 
Our analysis departs from Crinò and Epifani (forthcoming) in several respects. First, we focus explicitly on the food and beverage industry. This can be important as working at a narrow product level can offer additional insights by reducing any potential aggregation bias due to sector heterogeneity (see Hallak, 2010). The Italian food industry represents an 'ideal' case study to investigate this relationship. This is because a lot of anecdotal evidence emphasizes how the performance of Italian food products in international markets is driven by their high quality nature. Yet, and quite surprisingly, formal evidence of this link is rare, only based on export unit values, and not always in line with common intuition (see Ninni et al., 2006; Fischer, 2010). ${ }^{3}$ Second, we investigate the relationship for both the overall food industry and the 'sub-samples' related to firms producing typical 'Made in Italy' and 'Protected Designation of Origin' (PDO) products. This offers two main advantages. It gives the possibility to investigate if the perceived quality of these two product aggregations really matters for firm export behavior, and, moreover, it represents an indirect test to investigate whether the firm-level proxies for quality, suggested by industrial organization literature, correlate with the recognized quality of these food products. Third, among the proxies for capturing firm level quality we also consider information about the ISO 9000 certification, an international standard directly linked to product quality, which was recognized in previous studies as being important to characterize a firm's export performance (see Hallak and Sivadasan, 2009; Brown et al., 1998). Finally, we extend the analysis to the period 2004-2006, combining the 9th (2001-2003) and 10th Surveys (2004-2006) on Manufacturing Firms (Indagine sulle Imprese Manifatturiere) carried out by Unicredit-Capitalia.

There exists a large literature studying quality and quality assurance for agri-food products. ${ }^{4}$ In the last decades, as a consequence of globalization, product quality and safety issues have become central features in both domestic and international markets for food products (see, e.g., Krissof et al., 2002). This has triggered important research into food quality and its assurance, being especially focused on health and safety standards, related policy implications and impact on international food trade (see, e.g, Bureau et al., 1998; Swinnen, 2007; Henson and Jaffee, 2008). However, within this important strand of literature, little attention has been given to the role of product quality as a key driver of a firms' productivity and export performance.

Our analysis is closely related to recent attempts in the international trade literature to understand which characteristics of firms matter the most for export success. The traditional view is that more productive firms are larger, more likely to export, and serve more, and distant, markets (see Melitz, 2003; Bernard et al., 2007; Melitz and Ottaviano, 2008; Bernard et al., 2009). ${ }^{5}$ Yet, several recent stylized facts are at odds with this interpretation, as

\footnotetext{
${ }^{3}$ Ninni et al. (2006) studied the role of quality vs. price competition for Italian pasta, cheese, wine, and olive oil, finding weak evidence of quality premium and more often than expected, indications of price competition. Mixed evidence on the role of quality for export performance is also reported by Fischer (2010). Both papers used export unit values for their analyses.

${ }^{4}$ The analysis of food quality has followed different and alternative approaches First, the standard economic approach that formalizes quality as a process of vertica and/or horizontal differentiation. Second, focusing on the characteristics of quality attributes, and classifying them in search, experience and credence on the basis of the level of information available to the consumer (see Hooker and Caswell, 1995; Caswell and Mojduszka, 1996). Finally, following the quality perception approach developed within the applied psychology and marketing literature (e.g., Steenkamp, 1990). See Caswell et al. (2002) for a review and rationalization of this literature.

5 Similar patterns have been found for food and beverage firms (see Chevassus-Lozza and Latouche, 2012; Gullstrand, 2011). Specifically, ChevassusLozza and Latouche (2012), using a micro-dataset for 2004, studied the accessibility of European markets to French firms. Differently, Gullstrand (2011) investigated the importance of sunk export costs, using a very detailed dataset of Swedish food and beverage sector in the 1997-2002 period.
}

larger exporters are more skill intensive, use more expensive inputs, and charge higher, not lower, prices (Verhoogen, 2008; Manova and Zhang, forthcoming). Moreover, firms' total factor productivity do not seem to univocally determine they export status (Hallak and Sivadasan, 2009). Recent papers aimed at reconciling these apparent contradictory facts have extended the seminal productivity-heterogeneity framework in several directions, introducing heterogeneity into the fixed (sunk) costs of exporting (Das et al., 2007; Armenter and Koren, 2009), a richer treatment of the demand side of the model (Fajgelbaum et al., 2011; Crinò and Epifani, forthcoming; Altomonte et al., 2011; Bernard et al., 2011) and, last but not least, by incorporating heterogeneous quality across firms (Baldwin and Harrigan, 2011; Verhoogen, 2008; Crozet et al., 2012; Fajgelbaum et al., 2011; Crinò and Epifani, forthcoming). All these contributions tend to show that more efficient firms have higher export performance as they use more expensive and better quality inputs to sell higher-quality goods at higher prices.

Finally, our paper, like modern literature on quality and trade, is also related to the so-called Linder (1961) hypothesis. This author, long ago, emphasized product quality as an important determinant of the direction of trade, suggesting that richer countries tend to import more from countries producing higher-quality goods. However, the standard literature using the gravity equation and aggregated trade data find only mixed evidence of the Linder's effect (see Hallak (2010) for a recent survey). Similarly, Haq and Meilke (2011), using an augmented gravity equation, found little evidence of the Linder effect for agro-food products, notwithstanding the high intra-industry trade in that sector. ${ }^{6}$ Differently, our paper show that product quality is an important determinant of trade patterns, in a way consistent with the Linder (1961) hypothesis.

The remainder of the paper is organized as follows: the second section presents the theoretical framework, summarizing the key intuitions of a simple monopolistic competition trade model with firm heterogeneity in both productivity and product quality. The third section presents the data of the Italian food and beverage industry firms, summarizes how we retrieve our firms' level TFP estimates, and introduces the econometric strategy to test the main theoretical hypotheses. In fourth section, the results are presented and discussed. Finally, in the last section the main conclusions are drawn.

\section{Theoretical framework}

Consider a representative consumer characterized by the following utility function:

$U=\left[\int_{v \in V} q(v)^{1-\rho} c(v)^{\rho} d v\right]^{\frac{1}{\rho}}, \quad 0<\rho<1$,

where $V$ is a continuous set of varieties available for consumption, indexed by $v$ and represents a Cobb-Douglas bundle of physical quantity; $c(v)$ is consumption and $q(v)$ is quality of variety $v$ as perceived by the representative consumer. The demand for variety $v$ is obtained from the maximization of (1) subject to the usual budget constraint

$c(v)=q(v) \frac{p(v)^{-\sigma} R}{P^{1-\sigma}}$,

where $R$ is total income, $p(v)$ the price of variety $v, \sigma=(1-\rho)^{-1}>1$ is the constant elasticity of substitution between any two varieties, and $P$ is the ideal price index associated with the utility function (1).

The first key assumption of the Crinò and Epifani (forthcoming) model concerns the preferences of a representative consumer.

\footnotetext{
${ }^{6}$ More recently, Hallak (2010) demonstrated that the Linder hypothesis theoretically and empirically holds only when formulated at the sector-level.
} 
Unlike Melitz (2003), where the preferences are homothetic, in this model the representative consumer's preferences for quality are non-homothetic with respect to per capita income $(y)$. Let us assume that $q(v)=\lambda(v)^{\alpha(y)}$, where $\lambda(v) \geqslant 1$ denotes true product quality, and $\alpha(y)>0$ captures the elasticity of demand with respect to product quality. The relative demand for higher-quality products is higher in high-income countries if, and only if, the following relation holds: $\alpha\left(y^{\prime}\right)>\alpha\left(y^{\prime \prime}\right)$ for $y^{\prime}>y^{\prime \prime}$.

Consider now a partial equilibrium model of one sector economy open to international trade, where firms produce differentiated products under monopolistic competition and are heterogeneous in both productivity and quality. Within this framework it is possible to study the relationship between firms' revenue and product quality with respect to domestic per capita income vs. income from foreign destination countries. Let $d$ be a domestic market and $f$ a foreign market. Consider therefore a market $z \in\{d, f\}$, where $\theta$ measures firm productivity and $1 / \theta$ is the marginal cost to produce variety $v$. In the first part of the model, product quality is considered exogenous, next this assumption will be relaxed.

The profit maximizing price is $p_{z}=\tau_{z} / \rho \theta$, where $1 / \rho=\sigma / \sigma-1$ is a constant price-marginal cost mark-up, and $\tau_{z}>1$ is an iceberg trade cost. ${ }^{7}$ Putting into Eq. (2) the expression for $q_{z}$ and $p_{z}$, yields revenue in a market $z\left(r_{z}\right)$ for a firm characterized by a specific level of productivity $(\theta)$ and product quality $(\lambda)$.

$r_{z}(\theta, \lambda)=\theta^{\sigma-1} R_{z}\left(\frac{\rho P_{z}}{\tau_{z}}\right)^{\sigma-1} \lambda^{\alpha\left(y_{z}\right)}, \quad z \in\{d, f\}$.

Relation (3) implies that the elasticity of firm revenue towards product quality increases with the per-capita income of the destination $z$.

From (3) it is possible to study the ratio of exports to destination $f$ over domestic sales:

$$
\begin{aligned}
\frac{r_{f}}{r_{d}} & =\frac{R_{f}\left(P_{f} / \tau_{f}\right)^{\sigma-1}}{R_{d}\left(P_{d} / \tau_{d}\right)^{\sigma-1}} \lambda^{\alpha\left(y_{f}\right)-\alpha\left(y_{d}\right)} \text { which implies } \rightarrow \frac{d \ln \left(r_{f} / r_{d}\right)}{d \ln \lambda} \\
& =\alpha\left(y_{f}\right)-\alpha\left(y_{d}\right) .
\end{aligned}
$$

The above relation clearly suggests that $r_{f} / r_{d}$ is increasing or decreasing in product quality $\lambda$, for $y_{f}>y_{d}$ and $y_{f}<y_{d}$, respectively, and unrelated for $y_{f}=y_{d}$. Thus, the first important implication of the model clearly suggests that the elasticity of export intensity to quality is increasing in the per capita income of foreign destinations.

Next, after studying the relationship between export and product quality, an analysis is made of the implications of the second key assumption of the model, namely that a positive relationship exists between product quality and fixed costs. Such a relationship is evidently quite direct when one assumes that higher quality products require higher fixed costs, due to the idea that quality upgrading is linked to more intensive product development activities that require higher fixed costs, like R\&D and marketing activities. In summarizing this second part of the model, we focus just on the main intuitions, studying the relation between endogenous product quality and technical efficiency, the latter captured by revenue-TFP.

Let us assume that the firms produce a variety of quality $\lambda$, paying a fixed cost $(1 / \eta) \lambda^{\eta}$, where $\eta>0$ is the elasticity of the fixed costs to product quality. Moreover, assume that the firms produce goods of different quality, depending on the destination market,

\footnotetext{
${ }^{7}$ We are aware of the limitations of the iceberg trade costs assumption (e.g. Hummels and Skiba, 2004), although it is a standard approach in models with firmheterogeneity (see Melitz, 2003). The next section discusses how the model results change on relaxing this assumption.
}

therefore firms choose the quality of their product based on the characteristics of each destination market. ${ }^{8}$

The firms choose $\lambda_{z}$ to maximize profit in market $z$. Solving this problem, it is possible to show that the optimal product quality, $\lambda_{z}^{*}$, for each destination $z$, is equal to:

$\lambda_{z}^{*}=\left[\alpha\left(y_{z}\right) M_{z} \theta^{\sigma-1}\right]^{\frac{1}{\eta-\alpha\left(y_{z}\right)}}, \quad z \in\{d, f\}$,

where $\eta-\alpha\left(y_{z}\right)>0$ and $M_{z}$ is a measure of market size. Eq. (5) implies that the more productive firms produce higher-quality products for all market destinations. This is possible because they receive greater revenue from selling high-quality products in these markets, which allows them to spread the higher fixed costs paid for upgrading product quality over a greater revenue.

Plugging Eq. (5) into the revenue in market $z, r_{z}=\sigma M_{z} \theta^{\sigma-1} \lambda_{z}^{* \alpha\left(y_{z}\right)}$, taking log and differencing, it is possible to study the elasticity of the ratio $r_{f} / r_{d}$ to productivity:

$\frac{d \ln \left(r_{f} / r_{d}\right)}{d \ln \theta}=(\sigma-1)\left(\frac{\alpha\left(y_{f}\right)}{\eta-\alpha\left(y_{f}\right)}-\frac{\alpha\left(y_{d}\right)}{\eta-\alpha\left(y_{d}\right)}\right)$.

Eq. (6) implies that, conditional to exporting in destination $f{ }^{9}$ the export intensity is inversely (directly) related to productivity, namely $\frac{d \ln \left(r_{f} / r_{d}\right)}{d \ln \theta}<0$ and $\frac{d \ln \left(r_{f} / r_{d}\right)}{d \ln \theta}>0$, for $y_{f}<y_{d}$ and $y_{f}>y_{d}$, respectively, and unrelated for $y_{f}=y_{d}$. Thus, from (6) it emerges that the elasticity of export intensity to productivity increases with the per capita income of the foreign destination. The intuition is that highproductivity firms produce higher-quality goods, for which the relative demand is higher (lower) in high-(low)-income destinations. ${ }^{10}$ Clearly, here the role of productivity is indirect, as it is mediated by the product quality $\lambda$.

Summarizing, the model predicts two main hypotheses. The first, conditional to export, suggests that the correlation between export intensity and TFP is increasing with the per capita income of the foreign destinations. The second hypothesis, a consequence of a positive link between product quality and production cost and thus revenue-TFP, most importantly suggests that the link between TFP and export intensity across destinations should be driven by product quality.

\section{Discussion and extension}

A key question is, how do the above predictions hold true when considering the other determinants of firms' export behavior? Crinò and Epifani (forthcoming) discussed such implications from recent literature showing that, although several other determinants of export may be at work, they never affect the conclusions summarized above. ${ }^{11}$

However, it could be of interest to discuss how the results may be affected by relaxing the hypothesis on variable trade costs.

\footnotetext{
${ }^{8}$ This assumption delivers a simple solution for the elasticity of product quality to productivity. However, as shown by Crinò and Epifani (forthcoming), the qualitative results are similar under the equally plausible assumption that firms choose a uniform product quality across destinations.

${ }^{9}$ Indeed, due to fixed export costs, Eq. (6) holds conditional to exporting only to destination $f$, namely for $\theta>\theta_{f}$ where $\theta_{f}$ is the productivity cut-off for exporters to destination $f$.

${ }^{10}$ Crinò and Epifani (forthcoming) also highlight that, although revenue-TFP is closely related to product quality, it may also capture variation across firms in markups, which in this model are constant. Although markups may reflect pure demand shocks and pricing power, they are likely to be positively correlated with productivity and product quality, which may strengthen the positive correlation of revenue-TFP with both our key parameters.

11 Specifically, among other things, they discuss the implication of the model by considering multiproduct firms (see Bernard et al., 2011), country-specific fixed costs of exporting (see Eaton et al., 2004), and endogenous fixed costs of entry in foreign markets (see Arkolakis, 2010). They show that under all these conditions, the predictions of the model are, if any, even stronger.
} 
Indeed, in the model, in line with the theoretical literature, it has been assumed that the variable trade costs are of the iceberg type, namely ad valorem. However it is well known that the distinction between iceberg trade costs and per unit trade costs is not innocuous in trade models, as, in reality, transport costs are better represented as per unit costs (see Hummels and Skiba, 2004). Interestingly, per unit trade costs may provide an alternative explanation for the relationship between export intensity, quality and the income of foreign destination. In addition, the fact that, in the food industry, the border protection structure of many developed countries is often based on per unit (and composite) tariffs, rather than ad valorem tariffs, may induce a compositional effect in favor of higher quality exports to these destinations (see Ramos et al., 2010).

As shown by Crinò and Epifani (forthcoming), if trade costs are per unit, the relationship between export intensity and productivity/quality is affected by the size of the elasticity of marginal cost to productivity $(\xi) .^{12}$ For $\xi<1$, marginal costs is decreasing in productivity, and export intensity is inversely related to TFP also for similar income countries. This is because per unit trade costs represent a higher share of the marginal costs for high productivity firms, and therefore have a stronger negative impact on such firms' relative sales abroad.

Differently, for $\xi>1$, marginal costs are increasing in productivity and the elasticity of export intensity to productivity is positive, this is because the per unit trade costs now represent a lower share of the marginal costs for high-productivity firms. Moreover, because per unit trade costs increase with distance (see Hummels and Skiba, 2004), the above relationship would also increase with distance, namely firms producing higher quality products and with higher productivity can be expected to export more to distant markets. ${ }^{13}$

A final issue is related to the degree of sustainability between export activities and (horizontal) foreign direct investment (FDI). If the FDI option is more profitable within more productive firms, as shown by Helpman et al., (2004) then, by reducing the exports of these firms, FDI will induce a negative relation between export intensity and productivity, that should be particularly strong for high-income destinations. ${ }^{14}$ Moreover, as FDI tends to be a substitute of export, especially when trade costs are particularly high, the negative relationship between export intensity and productivity would be more likely in trade with more distant countries. However, as we will show in the empirical analysis, we find exactly the opposite relation.

\section{Empirical strategy}

To test the predictions discussed above we need firm-level data with information on firm export behavior across destinations, basic data to estimate revenue-TFP, and, last but not least, firm-level proxies for product quality. The next sections will introduce the dataset and the strategy to estimate TFP and the main model predictions.

\footnotetext{
12 All the above results hold true assuming that marginal costs is increasing in product quality, i.e. firms need to use more expensive inputs to produce higher quality products.

13 See also Baldwin and Harrigan (2011) for an in depth discussion about which conditions in heterogeneity-firm model satisfy a positive relation between product price/quality and distance.

${ }^{14}$ This is because horizontal FDI are a better substitute for export especially between similar countries. Thus, working with Italy, this should happen with high income countries.
}

\section{Data description}

We make use of an unbalanced panel of Italian food and beverage firms drawn from the 9th and 10th Surveys on Manufacturing Firms (Indagine sulle Imprese Manifatturiere) carried out by Unicredit-Capitalia. ${ }^{15}$ The overall sample contains firm level data on roughly 750 food firms with more than 10 employees observed in the period 2001-2006. The panel is stratified and rotating, so there is an overlapping of just 40 firms between the two surveys. The sample stratification is based on the 3-digit ISTAT ATECO 91 nomenclature (equivalent to NACE), size class and geographic area, and is representative of the population of the Italian food industry. In accordance with standard cleaning procedures, firms that present negative values for sales, material purchases, labor costs and capital stock were dropped.

In order to calculate firm's productivity with a Cobb-Douglas production function, we used a revenue-based measure of output that equals the value of shipments plus changes in stock of finished goods and capitalized costs, deflated with the corresponding ISTAT three-digit producer price index. As input we use the labor cost deflated with an ISTAT wage index, the book value of capital deflated with the ISTAT common price index for investment goods, and materials, defined as the difference between purchases and change in inventories of intermediate goods, deflated with the ISTAT common price deflator for intermediate inputs.

Table 1 reports the descriptive statistics on firm input and output. The average firm in the sample is characterized as follows: produces roughly 10 million Euros worth of output, employs about 30 workers, with a labor productivity (value added per worker) equal to 54 thousand Euros. With respect to the overall sample, exporting firms present a higher average value for all the considered variables, except for the number of employees that was equal in both samples.

Information on the firms' internationalization is for the years 2003 and 2006 in the first and second surveys, respectively. To take a preliminary look at the data, we divide the sample of exporting firms, roughly $60 \%$, into two groups, on the basis of the per capita income of the destination market: high income and low income destinations, respectively. The former group includes the firms' exports to EU15, North America and Oceania, the latter group includes exports to Latin America, Africa, the new EU member states and China. Note that, with the exclusion of China, the information about export destinations in the data set are available only at the group, and not country, level.

Table 2 gives some descriptive statistics for variables of interest. Specifically, we reported the level of firm export intensity, measured as firm export value over total sales (domestic and abroad), considering both high and low income destinations, and also subsamples of firms producing 'Made in Italy' products and those producing 'Protected Designation of Origin' (PDO) products. Firms producing 'Made in Italy' products are selected according to the 4-digit industry classification proposed by the Istituto Nazionale di Economia Agraria (INEA). ${ }^{16}$ Differently, firms producing PDO products were selected through a two step procedure. First, we selected just the firms located in the PDO areas and belonging to the corresponding PDO sector, according to the Italian Agricultural Ministry PDO

\footnotetext{
$\overline{15}$ Several previous studies used the Unicredit-Capitalia survey to investigate Italian manufacturing firms behaviour in export markets (see Barba Navaretti et al., 2007; Benfratello and Razzolini, 2008; Castellani and Giovannetti, 2010; Crinò and Epifani, forthcoming). However, our paper is the first one to focus exclusively on the sub sample of the food and beverage industry.

${ }^{16}$ According to the INEA classification, food and beverage sectors belonging to typical 'Made in Italy' in the 4-digit ATECO 91 nomenclature are: 15130,15300 $15411,15512,15520,15610,15620,15810,15811,15812,15820,15840,15850$ 15930.
} 
Table 1

Sample description. Source: our computation base on Unicredit-Capitalia surveys.

\begin{tabular}{|c|c|c|c|c|c|c|}
\hline & \multicolumn{2}{|l|}{ Mean } & \multicolumn{2}{|c|}{ Std. deviation } & \multicolumn{2}{|c|}{ Observations } \\
\hline & Overall & Exporter & Overall & Exporter & Overall & Exporter \\
\hline Output $\left(€,{ }^{\prime} 000\right)$ & 29,585 & 34,325 & 72,269 & 78,891 & 758 & 459 \\
\hline Output per worker ( $€$, ‘000) & 571 & 644 & 2514 & 3132 & 758 & 459 \\
\hline VA per worker (€, ‘000) & 97 & 120 & 680 & 870 & 770 & 468 \\
\hline Labor cost per worker $(€$, ‘000) & 47 & 57 & 253 & 324 & 770 & 468 \\
\hline Materials per worker (€, '000) & 337 & 354 & 972 & 1084 & 770 & 468 \\
\hline Capital stock per worker $\left(€,{ }^{\prime} 000\right)$ & 123 & 136 & 374 & 461 & 770 & 468 \\
\hline Number of employees & 78 & 78 & 219 & 150 & 793 & 478 \\
\hline
\end{tabular}

Notes: Variables definition: Output equals the value of shipments plus change in stock of finished goods and capitalized costs. Materials are the difference between purchases and change in inventories of intermediate goods. Capital stock is the book value of capital.

Table 2

Export intensity across destinations. Source: our computation base on Unicredit-Capitalia surveys.

\begin{tabular}{|c|c|c|c|c|c|c|}
\hline & \multicolumn{3}{|c|}{ Export intensity (\%) } & \multicolumn{3}{|c|}{ \# (\%) of firms } \\
\hline & Overall & Made in Italy & PDO & Overall & Made in Italy & PDO \\
\hline All destinations & 27.8 & 31.0 & 28.2 & $456(57.5 \%)$ & $233(29.3 \%)$ & $113(14.2 \%)$ \\
\hline High income destination & 23.2 & 26.6 & 23.6 & $423(53.3 \%)$ & $225(28.3 \%)$ & $107(13.4 \%)$ \\
\hline Low income destination & 10.0 & 8.8 & 9.7 & $144(18.1 \%)$ & $69(8.7 \%)$ & $39(4.9 \%)$ \\
\hline
\end{tabular}

Notes: Export intensity is the ratio of exports to total sales. High income destinations include EU15, North America (USA and Canada) and Oceania (Australia and New Zealand) countries. Low income destinations include New EU member states, China, Africa and Latin American countries. The reported figures are based on the average between 2003 and 2006 periods (see text).

list. Second, we verified whether the selected firms actually do produce PDO products, through a careful check of their internet website.

Italian food firms export mostly to high income destinations (423 firms out of 456 , about $93 \%$ of the exporters), the firms exporting to low income destinations being significantly lower (144 firms, about 31\%). Similarly, the firm' average export intensity (the ratio of exports over total sales) to high income destinations, equal to about $23 \%$, is significantly higher than export intensity to low income destinations, equal to only $10 \% .{ }^{17} \mathrm{~A}$ similar pattern emerges considering firms producing 'Made in Italy' products. By contrast, when firms producing PDO are considered, these differences are very small, suggesting that these firms are no longer different from the average, at least in terms of the export indicators.

Finally, to implement our empirical analysis, we also need data on destinations GDP per capita and average distances from Italy to each foreign destination. Real GDP per capita variables were obtained from the World Bank, World Development Indicators (WDI). Differently, the measures of average distance are based on data taken from CEPII (Centre d'Etude Prospectives et d'Informations Internationales). ${ }^{18}$

\section{Econometric approach}

\section{TFP estimation}

One of the central points of our analysis is the estimation of revenue-based measures of TFP. These measures reflect both technical efficiency and product quality (Klette and Griliches, 1996; Amiti and Konings, 2007). We estimate TFP with different methods to address the problem of simultaneity bias. Generally speaking, there is no simple and unique solution to this problem. Thus, following a standard approach (e.g. De Loecker, 2011), we estimated a set of TFP measures and then studied their correlation with export intensity. We used a Cobb-Douglas specification, which has the advantage of a simple log-linear form.

\footnotetext{
17 Export intensity to all destinations is higher than the average between high and low income, as we were forced to give no consideration to destination areas, where classification into high vs. low income is impossible. Specifically, we excluded 'Other Europe' and 'Other Asia' from the two groups as they include countries that are very heterogeneous in terms of per capita income.

${ }^{18}$ See the CEPII web site, http://www.cepii.fr/anglaisgraph/bdd/gravity.htm.
}

We started by estimating the production function parameters by OLS. However, as the OLS estimates may be biased due to measurement error and potential correlation between inputs and unobserved productivity shock, we also used the semi-parametric approaches of Olley and Pakes (1996) and Levinsohn and Petrin (2003). ${ }^{19}$ Appendix A, gives a description of how these TFP estimations were obtained.

Table A1 shows the estimated coefficients of our production function based on the three different techniques. In particular, all output elasticities are positive and, excluding the capital coefficient in the Levinsohn and Petrin procedure, precisely estimated. For each specification the bottom of the table reports estimated returns to scale: all the estimates are close to constant returns to scale. Finally note that the correlation among TFP estimates is quite high, and ranges from 0.95 (Olley-Pakes vs. Levinsohn-Petrin) to 0.98 (OLS vs. Levinsohn-Petrin).

\section{Export intensity, TFP and product quality}

With our firm-level TFP in hand we can now present the empirical strategy for testing the main model predictions. Our key dependent variable of interest is a firm-level ratio of export to total sales. This definition of export intensity is in line with the empirical literature, and have some practical advantages over the simple ratio between exports to domestic sales. This is because it is less susceptible to outlier and measurement errors, and gave us the possibility to also include observations where firms sell all their output to the international market. ${ }^{20}$

As the model predictions for a developed country like Italy hold, especially, for exports towards low income destinations (see Eq. (4)), we start by using an index of firm export intensity to low income destinations, measured as the ratio of exports to these areas over total sales, $E X P_{l} \equiv \frac{r_{l}}{r_{d}+r_{l}+r_{h}}{ }^{21}$ The first proposition of the model suggests the existence of a negative relationship between firm TFP

\footnotetext{
19 We implemented the Levinsohn-Petrin method in Stata 11 using the levpet routine (see Petrin et al. (2004) for additional information on this command).

${ }^{20}$ This is because firm exports to total sales tend to give too much weight to firms selling a small share of their output in the domestic market.

${ }^{21}$ These destinations include New EU member states, China, Africa and Latin American countries.
} 
Table 3

Export intensity to low income destinations, TFP and product quality.

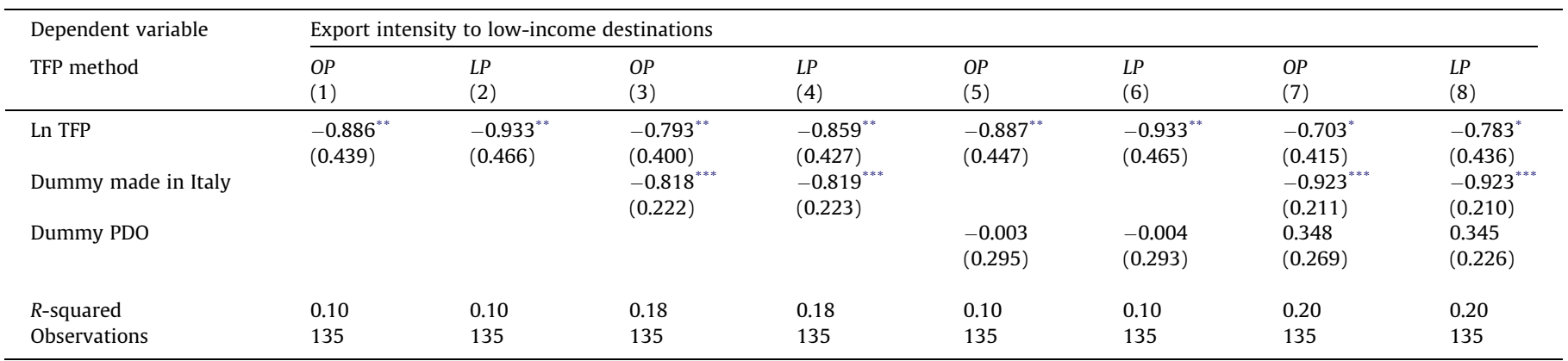

Notes: OLS regressions with robust standard errors in round brackets., All specifications include a full set of industry dummies, defined at the 3-digit level classification (see text).

* Significant at $10 \%$ level.

** Significant at $5 \%$ level.

Significant at $1 \%$ level.

and its export intensity to low income destinations, conditional to export. We test this hypothesis by running the following cross-sectional OLS regression on firm-level data:

$\ln \operatorname{EXP}_{l j}=\alpha_{0}+\alpha_{1} \ln T F P_{j}+\eta_{i}+\varepsilon_{j}$,

where $\operatorname{EXP}_{l j}$ is the export intensity to low income destinations for the firm $j, T F P_{j}$ is the firm-level total factor productivity, $\eta_{i}$ are industry fixed effects and, finally, $\varepsilon_{j}$ is an error term. The expectation is that the TFP coefficient should be negative, namely $\alpha_{1}<0$.

The second proposition of the model asserts that the key channel through which there exists a correlation between TFP and export intensity, conditional to export, is product quality, as an effect of the positive relations between revenue-TFP and product quality. We test these predictions in several different ways.

First, we rely on simple categorical dummies to indirectly capture the quality nature of Italian food products. Specifically, we construct two dummy variables for typical Made in Italy products and $P D O$ products, respectively. The first dummy equals 1 if a firm belongs to one of the 4-digit sectors of Made in Italy (0 otherwise); the second dummy, is equal to 1 for firms producing $P D O$ products ( 0 otherwise). Hence, in order to test the main hypothesis we simply add into (7) the two dummies, controlling for TFP. To the extent to which firms belonging to Made in Italy and/or producing PDO, produce higher quality products, we should expect their coefficients to be negative.

The second strategy follows Crinò and Epifani (forthcoming), and exploits the richness of the dataset. According to the literature (e.g. Sutton, 1998, 2007; Kugler and Verhoogen, 2008), product quality differentiation is normally associated with specific firm characteristics. Thus, we select the following variables to proxy for some of these firms' features linked to product quality differentiation: total investment expenditure, sale of innovative products, ICT investments, a dummy variable for R\&D investments, average wage as proxy for input quality, number of employees as proxy for size, a dummy variable for product innovation and, last but not least, a dummy variable for ISO 9000 quality certification. With respect to the last variable, there exists an extensive literature pointing to its relation with product quality (see Buttle, 1997; Brown et al., 1998; Withers and Ebrahimpour, 2001; Hallak and Sivadasan, 2009).

Each of these proxies for quality are regressed on TFP, to test if the expected positive relationship exists between them. Then, we generate a synthetic variables proxy for quality, extracting the principal component by factor analysis. Three quality proxies are generated. The first, $Q_{A}$, is the principal component of all the variables described above, except for firm size and input quality. The second proxy for quality, $Q_{B}$, is generated by adding a variable proxy for firm size, number of employees, to the variables used to generate $Q_{A}$. Finally, the third proxy for quality, $Q_{C}$, is generated by also adding a variable proxy for input quality, the firm's average wage, to the variables used for $Q_{B}$.

In a second step, after assessing how these firm-level quality variables correlate with TFP and dummies for Made in Italy and $P D O$, we test the main proposition of the model adding into (7) our proxies for quality in place of (or together with) TFP, in order to verify whether also in this case there exists a negative correlation between export intensity to low income destination and product quality.

Finally, we exploit the panel dimension of the dataset to check and extend our main findings. Specifically, we run panel regressions of the following form:

$\ln E X P_{z j}=\delta_{z}+\eta_{i}+\beta_{1} \ln X_{j}+\beta_{2}\left(\ln X_{j} \times y_{z}\right)+\mu_{z j}$,

where $E X P_{z j}$ is the firm j's export intensity to (foreign) destination $z$, $X_{j}$ is TFP or quality, $y_{z}$ is the per-capita income of the destination $z$ relative to Italy per-capita income and, finally, $\delta_{z}$ and $\eta_{i}$ are destinations and industry fixed effects, respectively. Our expectation is that the sign of coefficient $\beta_{2}$ should be positive. One key advantage of the above specification, is the possibility to control also for the robustness of our main findings to concurrent explanations like, especially, the effect of distance, as discussed in Discussion and extension. To this end we first took the distance in kilometers between Rome and the capital city of the main country of each destination, then we normalized it by the average distance across all the considered destinations.

\section{Econometric results}

Table 3 shows the regression results of Eq. (7), namely the relationship between export intensity to low income destinations and TFP. To save space, we rely only on Olley and Pakes (OP) and Levinsohn and Petrin (LP) TFP estimates. However, all the results reported below are robust to the use of TFP estimates based on simple OLS. ${ }^{22}$

As it is clear from the figures, the results strongly confirm that the TFP elasticity of export to low income destination is negative, large in magnitude, and statistically different from zero at $5 \%$ level (Columns 1-2). The result holds irrespective of the different TFP estimation methods, although the TFP elasticity to export is slightly higher for the Levinsohn and Petrin method. The estimated

\footnotetext{
${ }^{22}$ These additional results are available from the authors upon request.
} 
Table 4

Quality related variables and TFP (panel regressions).

\begin{tabular}{|c|c|c|c|c|}
\hline Dependent variable & $\begin{array}{l}\text { Investment expenditure } \\
\text { (1) }\end{array}$ & $\begin{array}{l}\text { Dummy for product innovation } \\
\text { (2) }\end{array}$ & $\begin{array}{l}\text { ICT investments } \\
\text { (3) }\end{array}$ & $\begin{array}{l}\text { Sales of innovative product } \\
(4)\end{array}$ \\
\hline Ln TFP (Olley-Pakes) & $\begin{array}{l}0.021^{* *} \\
(0.009)\end{array}$ & $\begin{array}{l}0.033^{* *} \\
(0.016)\end{array}$ & $\begin{array}{l}0.036^{* * *} \\
(0.010)\end{array}$ & $\begin{array}{l}0.093^{* *} \\
(0.47)\end{array}$ \\
\hline$R$-squared & 0.26 & 0.09 & 0.10 & 0.10 \\
\hline Observations & 1636 & 2221 & 1863 & 1767 \\
\hline Dependent variable & $\begin{array}{l}\text { Dummy for R\&D investments } \\
\text { (5) }\end{array}$ & $\begin{array}{l}\text { Dummy ISO } 9000 \\
(6)\end{array}$ & $\begin{array}{l}\text { Number of employees } \\
(7)\end{array}$ & $\begin{array}{l}\text { Average wage } \\
(8)\end{array}$ \\
\hline Ln TFP (Olley-Pakes) & $\begin{array}{l}0.080^{* * *} \\
(0.023)\end{array}$ & $\begin{array}{l}0.033^{* * *} \\
(0.005)\end{array}$ & $\begin{array}{l}0.028^{* *} \\
(0.014)\end{array}$ & $\begin{array}{l}0.096^{*} \\
(0.056)\end{array}$ \\
\hline$R$-squared & 0.07 & 0.07 & 0.10 & 0.07 \\
\hline Observations & 2235 & 2251 & 2224 & 2164 \\
\hline
\end{tabular}

Notes: OLS regressions with robust standard errors in round brackets. All variables are standardized with mean 0 and variance 1 . TFP is based on the Olley-Pakes estimates. All specifications include a full set of industry dummies, defined at the 4-digit level classification and time dummies (see text).

Significant at $10 \%$ level.

** Significant at $5 \%$ level.

**** Significant at $1 \%$ level.

Table 5

Correlation between TFP and proxy for quality (panel regressions).

\begin{tabular}{|c|c|c|c|c|c|c|c|c|c|}
\hline Dependent variable & $\begin{array}{l}Q_{A} \\
(1)\end{array}$ & $\begin{array}{l}Q_{B} \\
(2)\end{array}$ & $\begin{array}{l}Q_{C} \\
(3)\end{array}$ & $\begin{array}{l}Q_{A} \\
(4)\end{array}$ & $\begin{array}{l}Q_{B} \\
(5)\end{array}$ & $\begin{array}{l}Q_{C} \\
(6)\end{array}$ & $\begin{array}{l}Q_{A} \\
(7)\end{array}$ & $\begin{array}{l}Q_{B} \\
(8)\end{array}$ & $\begin{array}{l}Q_{C} \\
(9)\end{array}$ \\
\hline Ln TFP (Olley-Pakes) & $\begin{array}{l}0.066^{* * *} \\
(0.014)\end{array}$ & $\begin{array}{l}0.065^{* * *} \\
(0.011)\end{array}$ & $\begin{array}{l}0.051^{* * *} \\
(0.011)\end{array}$ & & & & & & \\
\hline Dummy made in Italy & & & & $\begin{array}{l}0.181^{* * * *} \\
(0.066)\end{array}$ & $\begin{array}{l}0.223^{\text {**** }} \\
(0.067)\end{array}$ & $\begin{array}{l}0.220^{* * * *} \\
(0.069)\end{array}$ & & & \\
\hline Dummy PDO & & & & & & & $\begin{array}{l}0.030 \\
(0.039)\end{array}$ & $\begin{array}{l}0.047 \\
(0.041)\end{array}$ & $\begin{array}{l}0.047 \\
(0.042)\end{array}$ \\
\hline$R$-squared & 0.14 & 0.14 & 0.14 & 0.17 & 0.18 & 0.18 & 0.16 & 0.18 & 0.18 \\
\hline Observations & 1421 & 1416 & 1415 & 915 & 911 & 900 & 915 & 911 & 900 \\
\hline
\end{tabular}

Note: OLS regressions with robust standard errors in round brackets. Quality A-C represent proxies for product quality obtained through factor analysis, by extracting the principal components of the quality proxy variables of Table 4 (see text). All variables are standardized with mean 0 and variance 1 . All specifications include a full set of industry dummies, defined at the 4-digit level classification and time dummies.

* Significant at $10 \%$ level.

** Significant at $5 \%$ level.

*** Significant at $1 \%$ level.

elasticity is large in magnitude, implying that a $1 \%$ increase in TFP is associated with about $0.9 \%$ fall in the export to low income destinations. Thus, firm-level export intensity to low income destinations appears quite sensitive to TFP, ceteris paribus.

The rest of the Table tests whether firms producing Made in Italy products (columns 3-4) and PDO (columns 5-6) have, after controlling for TFP, an export intensity significantly different from the average firm. In line with the theoretical predictions, the coefficients of these variables are, indeed, negative, although only the Made in Italy dummy is estimated with high precision ( $p$-value $<0.01$ ). Adding the two 'quality' dummies together (columns 7-8) confirms the previous results, although now the PDO dummy coefficient is positive, probably due to collinearity problems. ${ }^{23}$ It is also worth noting that when the dummy for Made in Italy is included, the magnitude of the TFP elasticity, although still significant at $5 \%$ level, shrinks by about 20\%, suggesting that the TFP elasticity to export intensity for firms producing Made in Italy is higher in (absolute) magnitude. This result gives a preliminary confirmation to the idea that product quality may effectively represent a first order explanation for the observed link between productivity and export behavior.

\footnotetext{
${ }^{23}$ Indeed, in this (small) sample of firms exporting to low income destinations, the degree of overlapping between firms producing Made in Italy and PDO is quite high. The simple correlation between the two dummies is indeed 0.40 in that sample, but shrinks to 0.20 in the overall sample.
}

In order to test the relationships directly, Tables 4 and 5 report results of regressing each of the selected proxies for quality on the TFP. The results clearly point to a positive relationship between TFP and all the quality variables, considered both individually (Table 4) and as synthetic quality proxies extracted through factor analysis (Table 5). Thus, as assumed by the theory, the findings point to a strong positive correlation between TFP and firm level proxies for quality. Moreover, in columns 4-9 of Table 5 we also check whether our firm level proxies for quality are correlated with Made in Italy and PDO dummies. These additional regressions give broad confirmation to that hypothesis, although only the Made in Italy dummy turns out to be positive and strongly significant. Thus in our sample, firms producing PDO display different behavior both in terms of export (see Table 3 ) and activities linked to quality upgrading like investments, process/product innovations and R\&D. ${ }^{24}$

After having assessed the positive correlation between TFP and quality indicators, we are now in the condition to test the crucial implication of the model. This is done by replacing, in Eq. (7), our

\footnotetext{
${ }^{24}$ A close inspection of the row data confirm that in the sample of PDO firms (vs. Made in Italy firms), we find fewer firms with investment ( $82 \%$ vs. 93\%), product innovation ( $29 \%$ vs. $37 \%$ ), ICT investments ( $76 \%$ vs. $80 \%$ ), sales of innovative products ( $34 \%$ vs. $42 \%$ ), and R\&D investments ( $48 \%$ vs. $51 \%$ ). The only category where PDO firms perform better is the ISO 9000 certification ( $85 \%$ vs. $81 \%$ ).
} 
Table 6

Export intensity to low income destinations and product quality.

\begin{tabular}{|c|c|c|c|c|c|c|c|c|c|}
\hline \multirow[t]{2}{*}{ Dependent variable } & \multicolumn{9}{|c|}{ Export intensity to low-income destinations } \\
\hline & $\begin{array}{l}Q_{A} \\
\text { (1) }\end{array}$ & $\begin{array}{l}Q_{B} \\
(2)\end{array}$ & $\begin{array}{l}Q_{C} \\
(3)\end{array}$ & $\begin{array}{l}Q_{A} \\
(4)\end{array}$ & $\begin{array}{l}Q_{B} \\
(5)\end{array}$ & $\begin{array}{l}Q_{C} \\
(6)\end{array}$ & $\begin{array}{l}Q_{A} \\
\text { (7) }\end{array}$ & $\begin{array}{l}Q_{B} \\
(8)\end{array}$ & $\begin{array}{l}Q_{C} \\
(9)\end{array}$ \\
\hline Proxy for quality & $\begin{array}{l}-0.497^{* * *} \\
(0.162)\end{array}$ & $\begin{array}{l}-0.325^{* *} \\
(0.144)\end{array}$ & $\begin{array}{l}-0.370^{* * *} \\
(0.130)\end{array}$ & $\begin{array}{l}-0.521^{* * *} \\
(0.162)\end{array}$ & $\begin{array}{l}-0.372^{* *} \\
(0.140)\end{array}$ & $\begin{array}{l}-0.377^{* * *} \\
(0.130)\end{array}$ & $\begin{array}{l}-0.572^{* * *} \\
(0.163)\end{array}$ & $\begin{array}{l}-0.395^{* * *} \\
(0.141)\end{array}$ & $\begin{array}{l}-0.406^{* * *} \\
(0.132)\end{array}$ \\
\hline Ln TFP (Olley-Pakes) & & & & $\begin{array}{l}-0.333 \\
(0.888)\end{array}$ & $\begin{array}{l}-0.555 \\
(0.904)\end{array}$ & $\begin{array}{l}-0.583 \\
(0.906)\end{array}$ & $\begin{array}{l}-0.128 \\
(0.893)\end{array}$ & $\begin{array}{l}-0.212 \\
(0.932)\end{array}$ & $\begin{array}{l}-0.226 \\
(0.931)\end{array}$ \\
\hline \multicolumn{10}{|l|}{ Destinations fixed effects } \\
\hline EU new member states & & & & & & & $\begin{array}{l}0.504^{*} \\
(0.279)\end{array}$ & $\begin{array}{l}0.556^{*} \\
(0.288)\end{array}$ & $\begin{array}{l}0.580^{* *} \\
(0.284)\end{array}$ \\
\hline Africa & & & & & & & $\begin{array}{l}-0.067 \\
(0.288)\end{array}$ & $\begin{array}{l}0.109 \\
(0.284)\end{array}$ & $\begin{array}{l}0.102 \\
(0.281)\end{array}$ \\
\hline China & & & & & & & $\begin{array}{l}0.719^{* * *} \\
(0.284)\end{array}$ & $\begin{array}{l}0.582^{* *} \\
(0.276)\end{array}$ & $\begin{array}{l}0.605^{* *} \\
(0.277)\end{array}$ \\
\hline Latin America & & & & & & & $\begin{array}{l}0.430 \\
(0.314)\end{array}$ & $\begin{array}{l}0.267 \\
(0.322)\end{array}$ & $\begin{array}{l}0.293 \\
(0.321)\end{array}$ \\
\hline$R$-squared & 0.39 & 0.35 & 0.38 & 0.40 & 0.37 & 0.38 & 0.47 & 0.42 & 0.43 \\
\hline Observations & 97 & 97 & 96 & 97 & 97 & 96 & 97 & 97 & 96 \\
\hline
\end{tabular}

Notes: OLS regressions with robust standard errors in round brackets. Proxies for quality are standardized variables with mean 0 and variance 1 . All specifications include a full set of industry dummies, defined at the 4-digit level classification (see text).

Significant at $10 \%$ level.

* Significant at $5 \%$ level.

* Significant at $1 \%$ level.

Table 7

Number of export destinations, TFP and quality.

\begin{tabular}{|c|c|c|c|c|c|c|}
\hline \multirow[t]{2}{*}{ Dependent variable } & \multicolumn{6}{|c|}{ Number of export destinations (from 1 to 8 ) } \\
\hline & $(1)$ & $(2)$ & (3) & $(4)$ & $(5)$ & (6) \\
\hline Ln TFP (Olley-Pakes) & $\begin{array}{l}0.239^{*} \\
(0.141)\end{array}$ & $\begin{array}{l}0.230^{*} \\
(0.137)\end{array}$ & $\begin{array}{l}0.276^{* *} \\
(0.141)\end{array}$ & $\begin{array}{l}0.287^{*} \\
(0.149)\end{array}$ & $\begin{array}{l}0.304^{* *} \\
(0.149)\end{array}$ & $\begin{array}{l}0.325^{* *} \\
(0.149)\end{array}$ \\
\hline Dummy made in Italy & & $\begin{array}{l}0.193^{* * *} \\
(0.060)\end{array}$ & & & & \\
\hline Dummy PDO & & & $\begin{array}{l}0.288^{* * * *} \\
(0.072)\end{array}$ & & & \\
\hline Proxy for quality $\left(Q_{A}-Q_{C}\right)$ & & & & $\begin{array}{l}0.151^{* * * *} \\
(0.035)\end{array}$ & $\begin{array}{l}0.164^{* * * *} \\
(0.039)\end{array}$ & $\begin{array}{l}0.161^{\text {**** }} \\
(0.037)\end{array}$ \\
\hline$R$-squared & 0.08 & 0.11 & 0.12 & 0.16 & 0.17 & 0.17 \\
\hline Observations & 438 & 438 & 438 & 308 & 308 & 308 \\
\hline
\end{tabular}

Notes: OLS regressions with robust standard errors in round brackets. In columns 4-6 the proxy for quality correspond to $Q_{A}, Q_{B}$ and $Q_{C}$, respectively. All specifications include a full set of industry dummies, defined at the 3-digit level classification and time dummies (see text).

Significant at $10 \%$ level.

** Significant at $5 \%$ level.

*** Significant at $1 \%$ level.

three proxies for product quality in place of TFP, in order to verify if the negative relation between TFP and export intensity to low income destinations, is indeed driven by firm heterogeneity in product quality. Table 6 , columns 1-3, shows the results. For all our quality proxies the estimated coefficient is, as expected, negative, and significant at $5 \%$ level or more. Because the three quality proxies are standardized variables, the magnitude of their estimated effect is comparable. Interestingly, when the quality proxy also incorporates firm size $\left(Q_{B}\right)$, the estimated effect on export intensity shrinks substantially, from 0.497 to 0.325 , but it is partially recovered when also the input quality dimension $\left(Q_{C}\right)$ is included. This result represents an indication that in the Italian food and beverage industry, firm size no longer represents a key firm characteristic affecting export behavior, a result fully in line with the most recent empirical evidence (see Hallak and Sivadasan, 2009; Bastos and Silva, 2010; Altomonte et al., 2011).

Columns 4-6 add to the specification also the TFP. Controlling for TFP, the results about the quality effects are even stronger and, moreover, the TFP coefficient although still negative is not significant. As a further check, in columns 7-9 we add export destination fixed effects, to control for omitted variable bias due to difference in size and price. This can be important, as any increase in the economic mass of the high-income countries leads to a reduction of the export intensity of firms exporting to low-income countries. However, adding destinations fixed effects, the results are virtually unchanged, suggesting that they are fairly robust across different specifications.

Finally, we also investigated the relationship between TFP, quality and firms' export behavior in terms of number of export destinations. Indeed, some previous firm-level evidence has shown that more productive firms export to a higher number of destination markets (Crozet et al., 2012; Bernard et al., 2007; Crinò and Epifani, forthcoming; Gullstrand, 2011). Thus, a natural extension consistent with the model is that the positive relation between TFP and the number of export destinations could be once again mediated by product quality. This is fully consistent with the idea that firms can spread higher fixed costs of quality upgrading over a larger output and across a higher number of foreign markets.

Table 7 reports the results of regressing the number of served markets on TFP and our proxies for quality. The evidence clearly points to positive and robust correlations. The number of export destinations covered by each firm, thus their so called extensive 
Table 8

Robustness checks (panel regressions).

\begin{tabular}{|c|c|c|c|c|c|c|c|c|c|}
\hline \multirow[t]{2}{*}{ Dependent variable } & \multicolumn{9}{|c|}{ Ln (Export intensity) } \\
\hline & $(1)$ & $(2)$ & (3) & $(4)$ & $(5)$ & $(6)$ & $(7)$ & $(8)$ & (9) \\
\hline Ln TFP (Olley-Pakes) & $\begin{array}{l}-0.726^{* *} \\
(0.308)\end{array}$ & $\begin{array}{l}-1.167^{* * *} \\
(0.422)\end{array}$ & $\begin{array}{l}-1.911^{* * *} \\
(0.620)\end{array}$ & $\begin{array}{l}-0.625 \\
(0.435)\end{array}$ & $\begin{array}{l}-0.784^{*} \\
(0.426)\end{array}$ & $\begin{array}{l}-0.817^{*} \\
(0.422)\end{array}$ & $\begin{array}{l}-1.954^{* *} \\
(0.861)\end{array}$ & $\begin{array}{l}-2.253^{* * *} \\
(0.832)\end{array}$ & $\begin{array}{l}-2.500^{* * *} \\
(0.817)\end{array}$ \\
\hline Ln TFP $*$ Relative income & $\begin{array}{l}0.515^{*} \\
(0.290)\end{array}$ & $\begin{array}{l}0.740^{* *} \\
(0.328)\end{array}$ & $\begin{array}{l}0.953^{* * *} \\
(0.353)\end{array}$ & $\begin{array}{l}0.430 \\
(0.378)\end{array}$ & $\begin{array}{l}0.557 \\
(0.374)\end{array}$ & $\begin{array}{l}0.584 \\
(0.371)\end{array}$ & $\begin{array}{l}0.965^{* *} \\
(0.473)\end{array}$ & $\begin{array}{l}1.172^{* *} \\
(0.462)\end{array}$ & $\begin{array}{l}1.286^{* * *} \\
(0.455)\end{array}$ \\
\hline Ln TFP $*$ Relative distance & & $\begin{array}{l}0.249^{* *} \\
(0.125)\end{array}$ & $\begin{array}{l}0.476^{* * *} \\
(0.182)\end{array}$ & & & & $\begin{array}{l}0.514^{*} \\
(0.267)\end{array}$ & $\begin{array}{l}0.587^{* *} \\
(0.258)\end{array}$ & $\begin{array}{l}0.649^{* *} \\
(0.253)\end{array}$ \\
\hline Ln TFP $*$ Number of countries & & & $\begin{array}{l}0.423^{*} \\
(0.249)\end{array}$ & & & & $\begin{array}{l}0.438 \\
(0.328)\end{array}$ & $\begin{array}{l}0.445 \\
(0.326)\end{array}$ & $\begin{array}{l}0.528 \\
(0.321)\end{array}$ \\
\hline Quality & & & & $\begin{array}{l}-0.417^{* * *} \\
(0.111)\end{array}$ & $\begin{array}{l}-0.463^{* * *} \\
(0.122)\end{array}$ & $\begin{array}{l}-0.461^{* * *} \\
(0.112)\end{array}$ & $\begin{array}{l}-0.841^{* * * *} \\
(0.235)\end{array}$ & $\begin{array}{l}-0.951^{* * *} \\
(0.245)\end{array}$ & $\begin{array}{l}-0.895^{* * *} \\
(0.204)\end{array}$ \\
\hline Quality $*$ Relative income & & & & $\begin{array}{l}0.357^{* * *} \\
(0.101)\end{array}$ & $\begin{array}{l}0.394^{* * *} \\
(0.112)\end{array}$ & $\begin{array}{l}0.393^{* * *} \\
(0.103)\end{array}$ & $\begin{array}{l}0.551^{* * *} \\
(0.137)\end{array}$ & $\begin{array}{l}0.616^{* * *} \\
(0.143)\end{array}$ & $\begin{array}{l}0.589^{* * * *} \\
(0.121)\end{array}$ \\
\hline Quality $*$ Relative distance & & & & & & & $\begin{array}{l}0.141^{*} \\
(0.0781)\end{array}$ & $\begin{array}{l}0.129^{*} \\
(0.0748)\end{array}$ & $\begin{array}{l}0.121^{*} \\
(0.0663)\end{array}$ \\
\hline Quality $*$ Number of countries & & & & & & & $\begin{array}{l}0.149^{*} \\
(0.0772)\end{array}$ & $\begin{array}{l}0.198^{* *} \\
(0.0783)\end{array}$ & $\begin{array}{l}0.176^{* *} \\
(0.0689)\end{array}$ \\
\hline$R$-squared & 0.428 & 0.43 & 0.432 & 0.469 & 0.476 & 0.481 & 0.480 & 0.490 & 0.495 \\
\hline Observations & 789 & 789 & 789 & 566 & 566 & 566 & 566 & 566 & 566 \\
\hline
\end{tabular}

Notes: the above panel regressions are obtained considering export intensity to all destinations, but 'other Europe' and 'other Asia'. All specifications include a full set of destinations fixed effects, industry fixed effects, and time fixed effects. For other variables definitions see text. Robust standard errors in round brackets.

* Significant at $10 \%$ level.

** Significant at $5 \%$ level.

Significant at $1 \%$ level.

margin of trade, is, as expected, higher for more productive firms (columns 1), for firms producing Made in Italy and PDO products (columns 2-3), as well as for our firm-level proxies for quality (columns 4-6). Thus, in line with previous evidence, we find that more productive firms, and firms producing higher quality products, also serve more export markets.

\section{Robustness checks and extensions}

The results reported in the previous section, although broadly in line with model predictions, may suffer several potential limitations. First, though it is remarkable to find such robust findings working with a sample of less than 100 firms, they are the result of using only a cross-section of firms that export to low income destinations. However, the model prediction is more general, suggesting that the elasticity of export intensity to productivity and quality should be increasing in the per capita income of the foreign destinations. ${ }^{25}$ Second, as discussed in Discussion and extension, there are other potential concurrent explanations for the predicted correlation between export intensity, TFP/quality, and the income of foreign destinations, like (horizontal) FDI and/or relevant per unit trade costs. Thus, a central point is to check whether our key findings are robust to the inclusion of proxy for trade costs, like distance.

Columns 1-3 of Table 8 run panel regressions based on Eq. (8) using TFP, and controlling for both destinations, sector and time fixed effects. As expected, the interaction term between TFP and the destination's per capita income is significantly positive, although only at the $10 \%$ level. ${ }^{26}$ Importantly, controlling for the interaction between TFP and distance (column 2) the results are even stronger, reinforcing the idea that the elasticity of export

\footnotetext{
${ }^{25}$ In a previous version of the paper we also studied the relationship between TFP/ quality and export intensity to high income destinations, running cross-section regressions like Eq. (7). These results although weaker, given the developed country status of Italy, are totally in line with those reported in Table 5. These additional results are available upon request.

${ }^{26}$ Note that, in this and in the other regressions of Table 8, only the interaction effects between TFP/quality with income, distance and the number of countries in each destination are included. This is because the direct effects of these variables, that are largely time invariant and destination specific, are subsumed in the full set of fixed effects.
}

intensity to productivity indeed increases with per capita income of foreign destinations. Moreover, and this is interesting, the elasticity of export intensity to TFP also increases with distance, a result inconsistent with the (horizontal) FDI argument, but totally in line with relevant per unit trade costs. We will return to this result later.

Column 3 adds the interaction between TFP and the number of countries for each destination. This can be important because there is evidence that the fixed costs of exporting are mainly countryspecific, thus many exporters will sell to only a few foreign countries. However, due to data limitation, we observe only exports to broad destinations, which in most cases include more countries. Thus there is an (unobserved) extensive margin of countries potentially inducing a selection bias that should lower the negative (positive) relation between TFP and export intensity to low-income (high-income) destinations. Note that, if this is the case then, controlling for the number of countries in each destination we should expect an increase in magnitude of the estimated elasticity between export intensity and TFP. This is indeed what we find in the data. First, the estimated coefficient of the interaction effect is positive and significant at $10 \%$ level, meaning that the elasticity of export intensity to TFP increases with the number of countries of each destination, a result consistent with country-specific fixed costs of exporting. Second, controlling for the number of countries at each destination the magnitude of the elasticity of export intensity to TFP increases.

Columns 4-6 add to the specification proxies for quality and their interaction with the income level of foreign destinations. We start from a parsimonious specification where we omit both the interactions with distance and the number of countries within each destination. The results are stark. Quality emerges as a first order explanation for the firms' export behavior, giving strong confirmation that the elasticity of export intensity to quality is increasing in the per capita income of foreign destinations. Once again, controlling for quality, the estimated effect of TFP loss its significant level. As a final check, columns 7-9 add to the specification interaction terms between TFP/quality and both the distance and the number of countries for each destination, respectively. The inclusion of these additional controls do not affect, to any degree, the quality coefficients that, as expected, increase in magnitude and remain significant at $1 \%$ level. Moreover, now also 
Table A1

TFP estimation results using different methods.

\begin{tabular}{llll}
\hline Dependent variable & \multicolumn{2}{l}{ Ln (Output) } & \\
\cline { 2 - 4 } TFP method & OLS & OP & LP \\
Parameter & $(1)$ & $(2)$ & $(3)$ \\
\hline Ln labor & $0.354^{* * *}$ & $0.331^{* * *}$ & $0.337^{* * *}$ \\
& $(0.010)$ & $(0.012)$ & $(0.023)$ \\
Ln capital & $0.040^{* * *}$ & $0.051^{* * *}$ & 0.040 \\
& $(0.008)$ & $(0.016)$ & $(0.045)$ \\
Ln material costs & $0.603^{* * *}$ & $0.611^{* * *}$ & $0.610^{* * * *}$ \\
& $(0.008)$ & $(0.009)$ & $(0.214)$ \\
Return to scale & 1.00 & 0.99 & 0.99 \\
Observations & 2275 & 2275 & 1737
\end{tabular}

Notes: In columns (1) robust standard errors in round brackets; In columns (2) and (3) standard error based on 100 bootstrap replications in round brackets (see Appendix A).

* Significant at $10 \%$ level.

** Significant at $5 \%$ level.

Significant at $1 \%$ levels.

the TFP coefficient and the interaction with income level turn out to be significant. As the last specifications are very demanding we conclude that our findings are very robust to potentially omitted variable (and selection) bias, and totally in line with the model predictions.

Finally, it is worth noting that also the interaction between product quality and distance is positive and significant, a result totally different from what Crinò and Epifani (forthcoming) found for the overall manufacturing industry using a more parsimonious specification. However, what is interesting here is the fact that the significant positive interaction effect between quality and distance is broadly in line with relevant per unit trade costs. This pattern is consistent with the Alchian and Allen (1964) effect on 'shipping the good apples out', highlighted recently by Hummels and Skiba (2004), and with the growing evidence showing that export unit values tend to be higher in more distant markets (see Bastos and Silva, 2010; Manova and Zhang, forthcoming; Baldwin and Harrigan, 2011). Yet there is the novelty that we find a similar relation using proxies for quality, instead of unit-values. Thus our findings also support the notion that what matters for a firm's competitiveness is quality-adjusted price, namely higher quality goods are more costly, more profitable, and better able to penetrate more distant markets.

\section{Conclusions}

Understanding the determinants of firms' export success and behavior is important for their implications on international trade patterns, the welfare effects of globalization and economic growth and development. Moreover, a deeper comprehension of the factors driving firms' export performance can facilitate the design of policies that promote trade.

Motivated by the recent literature on firms' heterogeneity and international trade, this paper, by exploiting the export behavior of a sample of 750 Italian food and beverage firms, tests the predictions of a trade model based on firms' heterogeneity in product quality and non-homothetic preferences. Using different measures of revenue-TFP and several direct and indirect proxies for product quality, we found strong support for the key model prediction, namely product quality matters for export performance. Specifically, the paper reveals robust evidence that the correlation between export intensity and TFP/quality increases with the percapita income of foreign destinations. Thus, more efficient firms have higher export performance as they use more expensive and quality inputs to sell higher-quality goods at higher prices. Moreover, we also found evidence that firms producing higher quality products export more to more distant markets, a result consistent with the idea that the presence of per unit transaction costs lowers the relative price of high-quality goods, as recently suggested by Hummels and Skiba (2004).

The above results may have potential interesting implications. First, they highlight that government priority should be given to encourage investment in R\&D and to establish technology policies that would allow firms to produce and export higher quality products. Clearly this statement is of particular importance for the developing countries access to richer markets. From this point of view, the growing concern about the effect of food quality and safety standards, on developing country exports - i.e. the view of standards as a barrier to trade - could be overemphasized. Indeed, if rich countries' food standards do not over marginalize small agrifood producers in developing countries, by inducing a process of quality upgrading they will increase, not decrease, the firms' access to these markets (see Henson et al., 2011).

Second, the notion that richer countries export higher quality foods to other rich countries - the Linder (1961) hypothesis - could suggest that European countries should not worry too much about the adverse effects of competition from developing countries' exports, due, for example, to further trade liberalization. This is because, price competition is softened by vertical differentiation through quality differences and, moreover the trade-reducing effect of non-homothetic preferences is exacerbated in the presence of firms' heterogeneity in productivity and quality.

Clearly we need more data and evidence to support these ideas properly. Thus, promising future research will involve investigations into whether quality vs. price competitive is the main driving force of the performance of developed countries' vs. developing countries' food exports.

\section{Acknowledgements}

The authors would like to thank participants at the 2010 SIDEA Conference, 2011 EAAE Congress, the editor and two anonymous referees for the Food Policy, for useful comments and suggestions.

\section{Appendix A. TFP estimation}

We start from a standard Cobb-Douglas production function $Y_{i t}=A_{i t} L_{i t}^{\beta_{1}} K_{i t}^{\beta_{k}} M_{i t}^{\beta_{m}}$, with $Y_{i t}$ is revenue-based output of firm $i$ in period $t, L_{i t}, K_{i t}$ and $M_{i t}$ are, respectively, labor, capital and materials inputs, $\beta_{l}, \beta_{k}$ and $\beta_{m}$ are the input coefficients to be estimated, and $A_{i t}$ is the Total factor productivity. While $L_{i t}, K_{i t}$ and $M_{i t}$ are all observable by the econometrician, $A_{i t}$ is unobservable to the researcher.

A log-linearization of the production function yields $y_{i t}=$ $\beta_{0}+\beta_{l} l_{i t}+\beta_{k} k_{i t}+\beta_{m} m_{i t}+\eta_{i t}$ where lowercase variables represent the natural logarithms of their respective uppercase variables, and $\ln A_{i t}=\beta_{0}+\eta_{i t}$, with $\beta_{0}$ a measure of the mean efficiency level across firms and over time, and $\eta_{i t}$ the time- and producer-specific deviation from that mean.

In order to calculate TFP, our variable of interest in the above equation is the error term, $\eta_{i t}$. Note that, to get a consistent OLS estimator of the production function, therefore extracting TFP as the residual, $\eta_{i t}$ must be uncorrelated with the input variables. However, using OLS to estimate our production function, $\eta_{i t}$ results correlate with the input variables, generating well known simultaneity problems (see Griliches and Mairesse, 1995).

Olley and Pakes (1996) and Levinsohn and Petrin (2003) proposed two similar methods to solve this problem, based on a semi-parametric estimation in which the error term, $\eta_{i t}$, is decomposed into two parts, $\eta_{i t}=\bar{\omega}_{i t}+\varepsilon_{i t}$, with $\bar{\omega}_{i t}$ representing the transmitted productivity component and $\varepsilon_{i t}$ an error term that is uncorrelated with input choices. The key difference between the two components is that $\bar{\omega}_{i t}$ is a state variable that impacts the 
productivity shocks and is observed by the firm but not by the econometrician. Hence OP and LP propose an estimation method to make observable the productivity shocks, finding an observable proxy for the productivity term $\bar{\omega}_{i t}$. In particular, the OP methodology uses investment as proxy, while the LP methodology uses material costs. OP and LP assume that, respectively, investment demand function and materials demand function, depend on a firm's state variables $k_{i t}$ and $\bar{\omega}_{i t}$. Assuming that these demand functions monotonically increase with TFP, then the TFP will be expressed in terms of observables, $\hat{\bar{\omega}}_{i t}=y_{i t}-\hat{\beta}_{k} k_{i t}-\hat{\beta}_{l} l_{i t}-\hat{\beta}_{m} m_{i t}$, where $\hat{\bar{\omega}}_{i t}$ is the $(\log$ of) TFP.

\section{References}

Aiginger, K., 1997. The use of unit values to discriminate between price and quality competition. Cambridge Journal of Economics 21 (5), 571-592.

Alchian, A.A., Allen, W.R., 1964. University Economics. Wadsworth, Belmont, Calif.

Altomonte, C., Colantone, I., Pennings, E., 2011. International Trade with Heterogeneous Firms and Asymmetric Product Varieties, Catholic University of Leuven (KUL) MSI Working Paper No. 1005.

Amiti, M., Konings, J., 2007. Trade liberalization, intermediate inputs, and productivity: evidence from Indonesia. The American Economic Review 97 (5), 1611-1638.

Arkolakis, K., 2010. Market penetration costs and the new consumers margin in international trade. Journal of Political Economy 118 (6), 1151-1199.

Armenter, R., Koren, M., 2009. Economies of Scale and the Size of Exporters, Mimeo.

Baldwin, R., Harrigan, J., 2011. Zeros, quality and space. Trade theory and trade evidence. American Economic Journal: Microeconomics 3 (2), 60-88.

Barba Navaretti, G., Bugamelli, M., Faini, R., Schivardi, F, Tucci, A., 2007. Le imprese e la specializzazione produttiva dell'Italia. Dal macrodeclino alla microcrescita? In: Report Presented at the Conference "I vantaggi dell'Italia", organized by Fondazione Rodolfo Debenedetti, Roma 22/3/2007.

Bastos, P., Silva, J., 2010. The quality of a firm's exports: where you export to matters. Journal of International Economics 82 (2), 99-111.

Benfratello, L., Razzolini, T., 2008. Firms' productivity and internationalisation choices: evidence for a large sample of manufacturing firms. In: Piscitello, L. Santangelo, G. (Eds.), Multinationals and Local Competitiveness. Franco Angeli, Milano.

Bernard, A.B., Jensen, J.B., Redding, S.J., Schott, P.K., 2007. Firms in international trade. Journal of Economic Perspectives 21 (3), 105-130.

Bernard, A., Jensen, J., Schott, P., 2009. Importers, exporters, and multinationals: a portrait of firms in the U.S. that trade goods. In: Dunne, T., Jensen, J.B., Roberts, M.J. (Eds.), Producer Dynamics: New Evidence from Micro Data. University of Chicago Press.

Bernard, A.B., Redding, S., Schott, P., 2011. Multi-product firms and trade liberalization. Quarterly Journal of Economics 126 (3), 1271-1318.

Brown, A., van der Wiele, T., Loughton, K., 1998. Smaller enterprises experiences with ISO 9000. International Journal of Quality \& Reliability Management 15 (3), 273-285.

Bureau, J.C., Marette, S., Schiavina, A., 1998. Non-tariff trade barriers and consumers' information: the case of the EU-US trade dispute over beef. European Review of Agricultural Economics 25 (4), 437-462.

Buttle, F., 1997. ISO 9000: marketing motivations and benefits. International Journal of Quality \& Reliability Management 14 (9), 936-947.

Castellani, D., Giovannetti, G., 2010. Productivity and the international firm: dissecting heterogeneity. Journal of Economic Policy Reform 13 (1), 25-42.

Caswell, J.A., Mojduszka, E.M., 1996. Using information labeling to influence the market for quality in food products. American Journal of Agricultural Economics 78 (5), 1248-1253.

Caswell, J.A., Noelke, C.M., Mojduszka, E.M., 2002. Unifying two frameworks for analyzing quality and quality assurance for food products. In: Krissof, B., Bohman, M., Caswell, J.A. (Eds.), Global Food Trade and the Consumer Demand for Quality. Kluwer Academic, New York.

Chevassus-Lozza, E., Latouche, K., 2012. Firms, markets and trade costs: access of French exporters to European agri-food markets. European Review of Agricultural Economics 79 (2), 257-288.

Crinò, R., Epifani, P., forthcoming. Productivity, quality, and export behavior. The Economic Journal.

Crozet, M., Head, K., Mayer, T., 2012. Quality sorting and trade: firm-level evidence for French wine. The Review of Economic Studies 79 (2), 609-644.

Das, S., Roberts, M.J., Tybout, J., 2007. Market entry costs, producer heterogeneity and export dynamics. Econometrica 75 (3), 837-873.

De Loecker, J., 2011. Product differentiation, multi-product firms and estimating the impact of trade liberalization on productivity. Econometric Society 79 (5), 1407-1451.

Eaton, J., Kortum, S., Kramarz, F., 2004. Dissecting trade: firms, industries, and export destinations. The American Economic Review 94 (2), 150-154.

Fajgelbaum, P., Grossman, G., Helpman, E., 2011. Income distribution, product quality, and international trade. Journal of Political Economy 119 (4), 721-765.

Falvey, R., Kierzkowski, H., 1987. Product quality* intra-industry trade and (im)perfect competition. In: Kierzkowski, H. (Ed.), Protection and Competition in International Trade. Basil Blackwell, Oxford.
Fischer, C., 2010. Food quality and product export-performance - an empirical investigation of the EU situation. Journal of International Food \& Agribusiness Marketing 22 (3-4), 210-233.

Flam, H., Helpman, E., 1987. Vertical product differentiation and north-south trade. American Economic Review 77 (5), 810-822.

Griliches, Z., Mairesse, J., 1995. Production Functions: The Search for Identification, NBER Working Paper No. 5067, Washington, DC

Grossman, G.M., Helpman, E., 1991. Quality ladders in the theory of growth. The Review of Economic Studies 58 (1), 43-61.

Gullstrand, J., 2011. Firm and destination-specific export costs: the case of the Swedish food sector. Food Policy 36 (2), 204-213.

Hallak, J.C., 2010. A product quality view of the Linder hypothesis. Review of Economics and Statistics 92 (3), 453-466.

Hallak, J.C., Schott, P., 2011. Estimating cross-country differences in product quality. The Quarterly Journal of Economics 126 (1), 417-474

Hallak, J.C., Sivadasan, J., 2009. Firms' Exporting Behavior Under Quality Constraints. NBER Working Papers No. 14928.

Haq, Z.U., Meilke, K., 2011. Does the Linder effect hold for differentiated agri-food and beverage product trade? Applied Economics 43 (27), 4095-4109.

Helpman, E., 2011. Understanding Global Trade. Harvard University Press, Cambridge, Massachusetts.

Helpman, E., Melitz, M.J., Yeaple, S.R., 2004. Export versus FDI with heterogeneous firms. The American Economic Review 94 (1), 300-316.

Henson, S., Jaffee, S., 2008. Understanding developing country strategic responses to the enhancement of food safety standards. The World Economy 31 (4), 548568.

Henson, S., Masakure, O., Cranfield, J., 2011. Do fresh produce exporters in SubSaharan Africa benefit from global GAP certification? World Development 39 (3), 375-386.

Hooker, N.H., Caswell, J.A., 1995. Trends in food quality regulation: implications for processed food trade and foreign direct investment. Agribusiness 12 (5), 411419.

Hummels, D., Klenow, P., 2005. The variety and quality of a nations exports. The American Economic Review 95 (3), 704-723.

Hummels, D., Skiba, A., 2004. Shipping the good apples out? An empirical confirmation of the Alchian-Allen conjecture. Journal of Political Economy 112 (6), 1384-1402.

Khandelwal, A., 2010. The long and short of quality ladders. Review of Economic Studies 77 (4), 1450-1476.

Klette, T.J., Griliches, Z., 1996. The inconsistency of common scale estimators when output prices are unobserved and endogenous. Journal of Applied Econometrics $11(4), 343-361$.

Knetter, M.M., 1997. The Segmentation of International Markets: Evidence from The Economist. NBER Working Papers No. 5878.

Krissof, B., Bohman, M., Caswell, J.A., 2002. Global Food Trade and the Consumer Demand for Quality. Kluwer Academic, New York.

Kugler, M., Verhoogen, E., 2008. The Quality-Complementarity Hypothesis: Theory and Evidence from Colombia. NBER Working Paper 14418.

Levinsohn, J., Petrin, A., 2003. Estimating production functions using input to control for unobservables. The Review of Economic Studies 70 (2), 317-342.

Linder, S.B., 1961. Essay on Trade and Transformation. John Wiley, New York.

Lipsey, R., 1994. Quality Changes and Other Influences on Measures of Export Prices of Manufactured Goods and the Terms of Trade Between Primary Products and Manufactures. NBER Working Papers No. 4671.

Manova, K., Zhang, Z., forthcoming. Export prices across firms and destinations. Quarterly Journal of Economics.

Melitz, M.J., 2003. The impact of trade on intra-industry reallocations and aggregate industry productivity. Econometrica 71 (6), 1695-1725.

Melitz, M., Ottaviano, G., 2008. Market size, trade, and productivity. Review of Economic Studies 75 (1), 295-316.

Ninni, A., Raimondi, M., Zuppiroli, M., 2006. The Success of "Made in Italy": An Appraisal of Quality-based Competitiveness in Food Markets, Economics Department Working Papers 2006-EP10. Department of Economics, Parma University.

Olley, S., Pakes, A., 1996. The dynamics of productivity in the telecommunications equipment industry. Econometrica 64 (6), 1263-1298.

Petrin, A., Poi, B.P., Levinsohn, J., 2004. Production function estimation in stata using inputs to control for unobservables. The Stata Journal 4 (2), 113-123.

Ramos, M.P., Bureau, J.C., Salvatici, L., 2010. Trade composition effects of the EU tariff structure: beef imports from Mercosur. European Review of Agricultural Economics 37 (1), 1-26.

Schott, P.K., 2004. Across-product versus within product specialization in international trade. Quarterly Journal of Economics 119 (2), 647-678.

Steenkamp, J.B., 1990. Conceptual model of the quality perception process. Journal of Business Research 21 (4), 309-333.

Sutton, J., 1998. Technology and Market Structure: Theory and History. MIT Press, Cambridge, Massachusetts.

Sutton, J., 2007. Quality, trade and the moving window: the globalization process. The Economic Journal 117 (524), F469-F498.

Swinnen, J. (Ed.), 2007. Global Supply Chain, Standards and the Poor. CAB International.

Verhoogen, E., 2008. Trade, quality upgrading and wage inequality in the Mexican manufacturing sector. Quarterly Journal of Economics 123 (2), 489-530.

Withers, B., Ebrahimpour, M., 2001. Impacts of ISO 9000 registration on European Firms: a case analysis. Integrated Manufacturing Systems 12 (2), 139-151. 